Justyna Antczak-Kujawin*

\title{
Diagnoza i terapia logopedyczna pacjenta w łagodnej fazie otępienia alzheimerowskiego
}

The diagnosis and speech therapy of a patient with early stage alzheimer's dementia

Słowa kluczowe: choroba Alzheimera, otępienie alzheimerowskie, diagnoza i terapia logopedyczna

Keywords: Alzheimer's disease, Alzheimer's dementia, diagnosis and speech therapy

\section{Wprowadzenie}

Choroba Alzheimera (Alzheimer's disease - AD) jest chorobą pierwotnie zwyrodnieniową mózgu, spowodowaną gromadzeniem się w nim białek o patologicznej strukturze (B-amyloidu, białka tau i innych), pod postacią amyloidowych starczych blaszek i alzheimerowskiego zwyrodnienia neurofibrylarnego, które przyczyniają się do zaniku neuronów i ich połączeń [Barcikowska, Bilikiewicz, 2004; Barcikowska, 2012, s. 58]. AD jest schorzeniem neurodegeneracyjnym o postępującym przebiegu. Przejawia się bowiem stopniowo narastającymi i nieodwracalnymi zaburzeniami poznawczo-językowymi, prowadzącymi do otępienia. AD jest najczęstszą przyczyną otępienia. Obecnie choruje na nią prawie 44 miliony ludzi na świecie, a w Polsce ponad 300 tysięcy osób [Szczudlik, 2016, s. 5].

Choroba Alzheimera rozwija się podstępnie i przebiega w sposób utajony. Dotyka człowieka na długo przed tym, nim zostanie zdiagnozowana. We wczesnej fazie choroby jej objawy są bowiem trudno uchwytne, a w wykonywanych u pacjenta badaniach mózgu stopień zmian patologicznych w małym stopniu koreluje $\mathrm{z}$ nasileniem objawów klinicznych otępienia [Jodzio, 2011]. Chorzy zwykle uzyskują więc diagnozę już w zaawansowanym etapie.

\footnotetext{
* Zakład Dialektologii Polskiej i Logopedii, Instytut Filologii Polskiej i Logopedii, Wydział Filologiczny Uniwersytetu Łódzkiego, ul. Pomorska 171/173, 90-236 Łódź, e-mail: justyna.antczak@uni.lodz.pl.
} 
W Polsce otępienie alzheimerowskie (inaczej: otępienie typu alzheimerowskiego, otępienie typu Alzheimera, otępienie w przebiegu choroby Alzheimera) jest rozpoznawane przede wszystkim na podstawie kryteriów diagnostycznych ICD-10 (zob. tabela 1) lub DSM-IV, zastąpionych niedawno w USA przez DSM-V (zob. tabela 2).

Tabela 1. Kryteria diagnostyczne otępienia alzheimerowskiego według ICD-10

Spełnione ogólne kryteria zespołu otępiennego* oraz:

1) podstępny początek ze stopniowym narastaniem objawów i pogarszaniem się stanu chorego;

2) brak dowodów klinicznych i wyników badań wskazujących na możliwość wystąpienia otępienia jako rezultatu innych chorób układowych lub chorób mózgu; brak nagłego, tak jak w udarze, początku oraz objawów ogniskowego uszkodzenia ośrodkowego układu nerwowego.

* Ogólne kryteria diagnostyczne otępienia, wypracowane przez zespoły specjalistów na Zachodzie, zostały omówione m.in. w pracy Andrzeja Szczudlika i Tadeusza Parnowskiego [2012].

Źródło: Klasyfikacja zaburzeń psychicznych..., 2000, za: Barcikowska, 2012, s. 62.

Tabela 2. Kryteria diagnostyczne otępienia alzheimerowskiego według DSM-IV

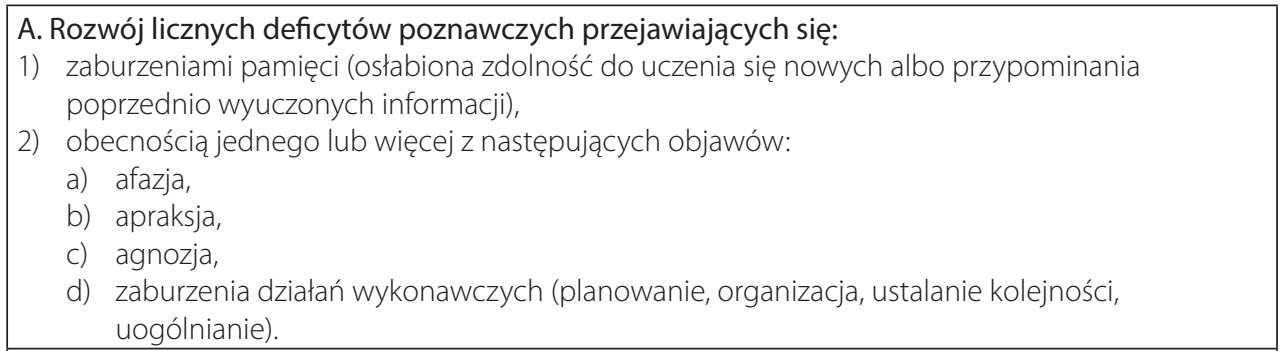

B. Zaburzenia poznawcze w kryterium A1 i A2 powodują znaczące zaburzenie funkcjonowania społecznego lub zawodowego i wykazują znaczące pogorszenie w porównaniu z poprzednim poziomem funkcjonowania,

C. Przebieg charakteryzuje się stopniowym początkiem i ciągłym narastaniem zaburzeń poznawczych,

D. Zaburzenia poznawcze w kryterium A1 i A2 nie są spowodowane żadnym z wymienionych poniżej czynników:

1) inne choroby ośrodkowego układu nerwowego, które powodują postępujące deficyty pamięci i innych funkcji poznawczych (choroba naczyniowa mózgu, choroba Parkinsona, choroba Huntingtona, krwiak podtwardówkowy, wodogłowie normotensyjne, guz mózgu),

2) stany i choroby, o których wiadomo, że mogą być przyczyną otępiania (niedoczynność tarczycy, niedobór witaminy B12, niedobór kwasu foliowego, niedobór niacyny, hiperkalcemia, kiła układu nerwowego, zakażenie HIV),

3) stany spowodowane substancjami toksycznymi.

E. Deficyty poznawcze nie występują wyłącznie w przebiegu zaburzeń świadomości.

F. Obecności tych deficytów nie można wyjaśnić lepiej występowaniem innego zaburzenia (choroby psychicznej) z zakresu osi I, np. depresji czy schizofrenii. 
W ostatnim czasie ukazały się także nowe kryteria diagnostyczne AD, zwane kryteriami NIA/AA, opracowane przez Narodowy Instytut Badań Starzenia i Stowarzyszenie Alzheimerowskie (zob. tabela 3).

Tabela 3. Nowe kryteria diagnostyczne otępienia w chorobie Alzheimera według NIA/AA

\section{Prawdopodobne otępienie w AD rozpoznaje się, jeżeli pacjent:}

1) spełnia ogólne kryteria otępienia oraz dodatkowo stwierdza się:

a) skryty początek - objawy rozpoczynają się stopniowo w ciągu miesięcy lub lat, a nie nagle - w ciągu godzin lub dni;

b) jednoznaczny wywiad mówiący o pogorszeniu funkcjonowania poznawczego na podstawie opisu lub obserwacji chorego;

c) początkowe i najwyraźniejsze ubytki funkcjonowania poznawczego, ustalone na podstawie wywiadu i badania klinicznego, należą do jednej z następujących kategorii:

- zaburzenia amnestyczne: jest to najczęstszy zespół manifestujący się w otępieniu w AD; objawy ubytkowe powinny obejmować upośledzenie uczenia się i przypominania świeżo wyuczonych informacji; powinny również występować inne cechy zaburzeń funkcjonowania poznawczego w co najmniej jednym dodatkowym zakresie;

- zaburzenia nieamnestyczne:

- manifestacja językowa: najwyraźniejsze ubytki dotyczą znajdowania słów, ale powinny występować również ubytki w innych zakresach funkcjonowania poznawczego;

- manifestacja wzrokowo-przestrzenna: najwyraźniejsze ubytki dotyczą poznawczych sprawności przestrzennych i obejmują agnozję przedmiotów, upośledzone rozpoznawanie twarzy, symultanagnozję i aleksję; powinny występować ubytki w innych zakresach funkcjonowania poznawczego;

- zaburzenia funkcji wykonawczych: najwyraźniejsze ubytki dotyczą upośledzonego wnioskowania, osądu i rozwiazywania problemów; powinny występować ubytki w innych zakresach funkcjonowania poznawczego;

d) rozpoznanie prawdopodobnego otępiania w AD nie powinno być stawiane, jeżeli istnieją dane wskazujące na:

- istotną współistniejącą chorobę naczyniową mózgu, definiowaną przez udar mózgu w wywiadzie powiązany czasowo z wystąpieniem lub nasileniem się upośledzenia funkcji poznawczych lub obecność mnogich albo rozległych zawałów lub nasilonych zmian hiperintensywnych w istocie białej

- lub kluczowe cechy otępienia z ciałami Lewy'ego inne niż samo otępienie,

- lub wyraźne cechy behawioralnej odmiany otępienia czołowo-skroniowego,

- lub wyraźne cechy odmiany semantycznej pierwotnej afazji postępującej lub pierwotnej afazji postępującej bez płynności mowy/z agramatyzmami,

- lub inną współistniejącą aktywną chorobę neurologiczną lub współistniejącą chorobę inną niż neurologiczna albo stosowanie leków, które mogłyby mieć istotny wpływ na funkcjonowanie poznawcze. 
Tabela 3 (cd.)

Prawdopodobne otępienie w AD ze zwiększonym stopniem pewności:

1) prawdopodobne otępienie $w$ AD z udokumentowanym pogorszeniem: istnieją dane wskazujące na postępujące pogorszenie funkcjonowania poznawczego w kolejnych ocenach opartych na informacjach od osoby dobrze znającej pacjenta i na badaniu funkcji poznawczych - albo w postaci badania neuropsychologicznego, albo standaryzowanych badań stanu umysłowego;

2) prawdopodobne otępienie w AD u nosiciela mutacji genetycznej powodującej AD: istnieją dane wskazujące na sprawczą mutację genetyczną (w genie APP, PSEN1 lub PSEN2);

3) prawdopodobne otępienie w AD z danymi wskazującymi na proces patofizjologiczny AD: stanowią o tym wyniki badań markerów biologicznych (markery biologiczne odkładania się w mózgu białka amyloidu beta; markery biologiczne zejściowego zwyrodnienia lub uszkodzenia neuronalnego).

Źródło: McKhann, Knopman, Chertkow i wsp., 2011, s. 263-269, za: Barcikowska, 2012, s. 63-64.

\section{Zaburzenia mowy i komunikacji w otępieniu alzheimerowskim}

Zaburzenia mowy w otępieniu typu alzheimerowskiego nie są izolowanym objawem, tzn. współistnieją z innymi objawami AD - zaburzeniami funkcji poznawczych czy zaburzeniami zachowania. Rozwijają się one na przestrzeni kilku lat. Mają więc charakter progresywny. O ile w początkowej fazie otępienia alzheimerowskiego zaburzenia językowe są trudno uchwytne, to w miarę narastania zaburzeń dementywnych pogłębiają się i stają się bardziej zauważalne. W zaawansowanej fazie otępienia w AD następuje całkowity rozpad systemu komunikacyjnego, objawiający się zniesieniem zdolności mówienia i rozumienia, czyli mutyzmem.

Zaburzenia językowe w otępieniu alzheimerowskim dotyczą przede wszystkim zaburzeń sprawności leksykalno-semantycznej. Przyjmują one postać tzw. mowy pustej, czyli „mowy bez treści z niewielkim zasobem konkretnego słownictwa i małą liczbą pojęć [Olszewski, 2008, s. 200]. Zaburzenia na poziomie leksykalno-semantycznym języka w łagodnej i umiarkowanej fazie otępienia alzheimerowskiego objawiają się ponadto trudnościami z odnajdywaniem właściwego słowa. Mowę osób z AD charakteryzuje więc dysnomia/anomia, obniżony poziom gotowości słowa, tzw. zjawisko „mam na końcu języka” oraz zaburzenia fluencji słownej. Kolejnym zasadniczym objawem zaburzeń językowych w AD są zaburzenia sprawności narracyjnych. W wypowiedziach dialogowych osób z otępieniem alzheimerowskim stwierdza się bowiem: problemy z referencją, nieoczekiwane zmiany tematów rozmów, wtrącanie słów, wyrażeń lub tematów z poprzednich rozmów (perseweracje), wycofywanie się z rozmowy, długie pauzy, milczenie lub nadmierny werbalizm, automatyzmy i komentarze metajęzykowe. Ponadto u osób w łagodnej i umiarkowanej fazie otępienia alzheimerowskiego występują problemy z budowaniem wypowiedzi pisemnych oraz trudności w czytaniu ze zrozumieniem [Domagała, 2007; 2015a; 2015b].

Zaburzeniu w otępieniu alzheimerowskim ulegają ponadto sprawności komunikacyjne. U pacjentów z otępieniem w AD dotyczą one przede wszystkim językowej 
sprawności społecznej oraz sytuacyjnej. Postępująca deterioracja umysłowa w chorobie Alzheimera zaburza głównie umiejętność realizowania językowych ról społecznych i reguł sytuacyjnych. W obszarze zaburzeń komunikacji sytuują się także zaburzenia sprawności interakcyjnej objawiające się trudnościami w budowaniu wypowiedzi (monologowych, dialogowych) prawidłowych pod względem logicznotreściowym [Domagała, 2007; 2015a; 2015b].

Wśród objawów osiowych zaburzeń językowych i komunikacyjnych w przebiegu otępienia alzheimerowskiego wymienia się zatem: zaburzenia językowej sprawności leksykalno-semantycznej, obniżenie złożoności syntaktycznej wypowiedzi oraz zaburzenia struktury tekstu przy braku zaburzeń w zakresie podsystemu fonetyczno-fonologicznego języka i dość długo zachowanej poprawności gramatycznej oraz umiejętności językowych, tj. czytania i pisania [Domagała, 2007; 2015a; 2015b].

\section{Diagnoza logopedyczna pacjenta z otępieniem alzheimerowskim}

Diagnoza logopedyczna w przypadku otępienia alzheimerowskiego przybiera charakter interdyscyplinarny. Ocena logopedyczna pacjenta jest bowiem prowadzona w oparciu o dane z diagnozy medycznej (wyniki badania neurologicznego, psychiatrycznego, neuropsychologicznego) dotyczące funkcjonowania poznawczego oraz pozapoznawczego osoby badanej. Taka wielospecjalistyczna procedura badania pozwala opisać zachowania językowe i komunikacyjne pacjenta na tle innych zaburzeń (np. procesów poznawczych, zaburzeń zachowania, zaburzeń psychotycznych).

W niniejszym artykule przedstawiono proces diagnozy i terapii logopedycznej pacjenta w łagodnej fazie otępienia alzheimerowskiego. Omówiono wyniki diagnozy logopedycznej, wskazano metody postępowania diagnostycznego oraz cele, strategie i metody terapii logopedycznej.

Diagnoza logopedyczna była przeprowadzona w maju 2017 roku i obejmowała ${ }^{1}$ :

1) wywiad logopedyczny z chorym i jego opiekunem, który pozwolił zgromadzić dane na temat sprawności językowej i komunikacyjnej oraz funkcji poznawczych pacjenta z uwzględnieniem zarówno jego aktualnego stanu, jak również funkcjonowania w okresie przed zachorowaniem i zmian zachodzących w funkcjonowaniu pacjenta w przebiegu choroby;

2) analizę wyników badań specjalistycznych, w tym badań neuropsychologicznych (dostarczających informacji na temat funkcji poznawczych, takich jak pamięć, myślenie, uwaga, orientacja w miejscu i czasie, funkcje percepcyjnych), neurologicznych (dostarczających informacji na temat stanu i funkcjonowania

1 Schemat diagnozy logopedycznej w przypadku otępienia alzheimerowskiego podaję za Anetą Domagałą [2015b]. 
układu nerwowego) oraz psychiatrycznych (zorientowanych na ocenę stanu psychicznego i zachowania);

3) obserwację i badanie logopedyczne ukierunkowane na ocenę: ekspresji mowy, rozumienia oraz czytania i pisania.

Przeprowadzając badanie logopedyczne posłużono się wybranymi narzędziami diagnostycznymi wspomagającymi proces diagnozowania zaburzeń językowych i komunikacyjnych pacjentów z otępieniem typu alzheimerowskiego. Oceny sprawności językowej i komunikacyjnej dokonano bowiem przy użyciu wybranych prób diagnostycznych (takich jak ocena rozumienia słów, poleceń i złożonych materiałów językowych, ocena fluencji słownej oraz ocena czytania i pisania) z Bostońskiego Testu do Diagnozy Afazji (Boston Diagnostic Aphasia Examination - BDAE) [Goodglass, Kaplan, 1983] oraz autorskiego testu do badania sprawności leksykalno-semantycznej w otępieniu [Antczak-Kujawin, 2017].

\section{Opis przypadku}

\section{Dane podstawowe}

Badany to mężczyzna w wieku 85 lat $\mathrm{z}$ wykształceniem wyższym w zakresie nauk przyrodniczych i ochrony środowiska. Jest inżynierem rolnictwa. Od 70. roku życia przebywa na emeryturze. Jest mieszkańcem małego miasta (położonego w województwie łódzkim). Mieszka wraz z żoną w domu rodzinnym.

Mężczyzna od około 82. roku życia pozostaje pod opieką neurologiczną i psychiatryczną ze względu na problemy lękowe oraz nasilające się zaburzenia pamięci. W wieku 85 lat u badanego rozpoznano otępienie w chorobie Alzheimera. Na podstawie diagnozy klinicznej otępienia ustalono, że pacjent w badaniu funkcji poznawczych przy użyciu Krótkiej Skali Oceny Stanu Psychicznego (MMSE) uzyskał 24 punkty, Skali Oceny Choroby Alzheimera (ADAS) - 25 punktów, Skali Ogólnej Deterioracji Reisberga (GDS) - 4 stopień. Wyniki uzyskane w testach psychiatrycznych i neuropsychologicznych potwierdzają więc łagodną fazę otępienia alzheimerowskiego o późnym początku.

W obrazie zaburzeń funkcjonowania poznawczego wskazuje się na występowanie u badanego nasilających się zaburzeń pamięci (przede wszystkim zaburzeń w przypominaniu informacji, słów po odroczeniu), osłabionej koncentracji uwagi, zaburzeń orientacji allopsychicznej. Zauważalne są ponadto: osłabienie nastroju, zaburzenia zachowania $\mathrm{z}$ nasilającymi się problemami lękowymi, utrata zainteresowań i wycofywanie się z preferowanych uprzednio (czyli w okresie przed zachorowaniem) form aktywności. 


\section{Ocena logopedyczna}

W badaniu logopedycznym ocenie podlegały: ekspresja mowy, rozumienie mowy oraz czytanie i pisanie. W zakresie badania ekspresji i rozumienia mowy skoncentrowano się szczególnie na ocenie sprawności leksykalno-semantycznej oraz sprawności narracyjnej. W tym celu pacjentowi zaproponowano wykonanie kilku prób diagnostycznych:

1) nazywanie obrazków,

2) nazywanie na podstawie usłyszanej definicji²,

3) badanie fluencji słownej,

4) budowanie wypowiedzi monologowych i dialogowych,

5) budowanie tekstu w formie opowiadania na podstawie ilustracji.

U badanego odnotowano trudności w zakresie aktualizacji słów. Podczas badania pacjent wielokrotnie miał problemy z przypomnieniem sobie właściwej nazwy. Deficyty leksykalne obejmowały słownictwo codzienne (nazwy pospolite o wysokiej frekwencji użycia) i pojawiały się zarówno podczas swobodnej rozmowy, jak i podczas prób nazywania obrazków, przywoływania nazwy na podstawie usłyszanej definicji czy budowania opowiadania. W przypadku trudności leksykalnych pacjent skłaniał się do stosowania różnego rodzaju językowych strategii zastępczych. Wśród najczęściej używanych przez badanego technik kompensacyjnych należy wymienić:

1) kompensację za pomocą gestów,

2) kompensację za pomocą pisma,

3) ominięcia (stosowanie długich pauz skutkujące brakiem odpowiedzi),

4) stosowanie parafazji fonologicznych,

5) stosowanie parafazji semantycznych,

6) stosowanie peryfraz (omówień),

7) wycofywanie się z rozmowy,

8) rezygnację z odszukiwania nazwy w pamięci oraz informowanie wprost o swoich trudnościach przez stosowanie komentarzy typu nie wiem; wiem, ale nie pamiętam; nie przypomnę sobie itp.

$\mathrm{U}$ badanego zarejestrowano obniżoną fluencję słowną. W próbie polegającej na wymienieniu jak największej liczby nazw zwierząt w przeciągu minuty badany podał 12 słów, w tym 2 nazwy spoza kategorii semantycznej oraz 2 powtórzenia. Zubożenie fluencji słownej przejawia się u pacjenta małą liczbą wymienianych elementów, obecnością dość długich pauz, stosowaniem powtórzeń i nazw spoza kategorii.

2 Próby diagnostyczne, tj. nazywanie obrazków i nazywanie na podstawie usłyszanej definicji, to autorskie próby stworzone na potrzeby badań własnych zorientowanych na ocenę sprawności leksykalno-semantycznej u osób w wieku senioralnym starzejących się fizjologicznie oraz osób z otępieniem alzheimerowskim. Podczas badania nazywania obrazków pacjent był proszony o nazwanie 60 czarno-białych obrazków przedstawiających przedmioty, osoby i czynności. Natomiast w badaniu nazywania na podstawie usłyszanej definicji pacjentowi odczytywano opis jakiegoś przedmiotu, osoby lub czynności - badany po usłyszeniu definicji proszony był o podanie właściwej nazwy. 
Badanie sprawności narracyjnej wykazało, że pacjent chętnie inicjuje kontakt werbalny, odpowiada na pytania wymagające zbudowania dłuższej wypowiedzi. Mężczyzna konstruował wypowiedzi monologowe oraz dialogowe. Budował opowiadanie na podstawie ilustracji. Jednak ze względu na problemy leksykalno-semantyczne struktura tworzonych przez badanego wypowiedzi niejednokrotnie ulegała zaburzeniu. Trudności z przypomnieniem sobie właściwego słowa skutkowały urywaniem zdań czy utratą wątku. Wypowiedzi kreowane przez pacjenta były jednak poprawne pod względem gramatycznym.

W zakresie badania rozumienia nie zaobserwowano większych trudności. Pacjent nie miał problemów ze wskazywaniem odpowiednich obrazków po usłyszeniu nazwy oraz z rozumieniem poleceń prostych. Trudności pojawiały się w próbie badającej rozumienie poleceń złożonych oraz treści tekstów czytanych przez diagnostę. Trudności te wynikały przede wszystkim z zaburzeń funkcji poznawczych, przede wszystkim z obserwowanych u badanego postępujących zaburzeń pamięci krótkotrwałej.

Umiejętność czytania i pisania była u pacjenta zachowana. Podczas prób czytania słów oraz prostych zdań nie odnotowano trudności. W przeprowadzonych próbach oceniających umiejętność pisania, takich jak pisanie swoich danych personalnych, przepisywanie zdań, zapisywanie z pamięci ciągu liczb i liter alfabetu, pisanie ze słuchu pojedynczych liter, cyfr, prostych słów, również nie obserwowano problemów. Co więcej, niejednokrotnie w przypadku problemów leksykalnych pacjent kompensował deficyty właśnie pismem. W tabeli 4 przedstawiono ilościową analizę wyników badania logopedycznego.

Tabela 4. Wyniki ilościowe badania logopedycznego

\begin{tabular}{|l|r|}
\hline \multicolumn{1}{|c|}{ Rodzaj ocenianej sprawności i umiejętności } & Wynik badania \\
\hline Sprawność leksykalno-semantyczna & 27 \\
- Nazywanie na podstawie obrazków (maks. 60) & 22 \\
- Nazywanie na podstawie usłyszanych definicji (maks. 60) & 8 \\
\hline - Ocena fluencji słownej (liczba słów/60 sek.) & 72 \\
\hline Rozumienie & 7 \\
- Rozumienie wyrazów (maks. 72) & 6 \\
- Rozumienie poleceń (maks. 15) & \\
- Rozumienie złożonych materiałów językowych (maks. 12) & 30 \\
\hline Czytanie & 10 \\
- Czytanie słów (maks. 30) & \\
- Czytanie głośne zdań (maks. 10) & 47 \\
\hline Pisanie & 10 \\
\hline
\end{tabular}




\section{Programowanie terapii logopedycznej}

Każda terapia logopedyczna pacjenta z otępieniem alzheimerowskim powinna uwzględniać dwa główne cele [Domagała, 2015b, s. 1007]:

1) zachowanie, w możliwie najwyższym stopniu na danym etapie choroby, sprawności językowej osoby chorej,

2) utrzymywanie aktywności językowej i kontaktów społecznych, stymulowanie zachowań językowych i komunikacyjnych, zapobieganie wyobcowaniu i izolacji społecznej.

Programując terapię logopedyczną dla pacjenta, którego przypadek omówiono w niniejszym artykule, wyznaczono następujące kierunki postępowania logopedycznego:

1) stymulowanie sprawności językowej, w szczególności sprawności leksykalnej i narracyjnej, przy jednoczesnym usprawnianiu funkcji poznawczych (w głównej mierze - pamięci, myślenia, uwagi, orientacji w czasie i przestrzeni),

2) usprawnianie umiejętności językowych, tj. czytania i pisania,

3) stymulowanie sprawności komunikacyjnej przez aktywizowanie pacjenta w typowych sytuacjach komunikacyjnych i w kontaktach z otoczeniem,

4) pomoc w przezwyciężaniu trudności językowych i komunikacyjnych, przeciwdziałanie skutkom negatywnym, takim jak wycofanie z kontaktów społecznych, frustracja czy lęk komunikacyjny.

Zajęcia logopedyczne prowadzono indywidualnie z pacjentem (tzw. terapia bezpośrednia) przez rok. Stosowano terapię reminiscencyjną (wspomnieniową). Podczas spotkań terapeutycznych wspólnie z pacjentem prowadzono tzw. księgę pamięci, czyli zeszyt wspomnień (memory books). Umieszczano w nim, w zależności od realizowanego bloku tematycznego, informacje ważne dla pacjenta, na przykład jego dane biograficzne, fotografie rodziny, zapiski wydarzeń z życia itp. Wypełniony z pomocą logopedy zeszyt wykorzystywano następnie podczas zajęć stymulujących sprawność językową, komunikacyjną i poznawczą ${ }^{3}$.

Podczas terapii prowadzono z pacjentem rozmowy oraz różnego rodzaju ćwiczenia językowo-poznawcze, na przykład opisywanie ilustracji, fotografii czy rysunków, snucie wspomnień, nazywanie przedmiotów rzeczywistych i na ilustracjach, nazywanie czynności i cech przedmiotów, czytanie i omawianie historyjek, artykułów prasowych czy fragmentów książek, aktualizacja słów rozpoczynających się od danej głoski, aktualizacja słów z danej kategorii semantycznej, zapisywanie słów (tworzenie zeszytu ze słowami, których przypomnienie w różnych sytuacjach życia codziennego sprawia pacjentowi trudności), uzupełnianie niedokończonych zdań czy znanych przysłów i frazeologizmów, tworzenie kalendarza ważnych dat, sprawdzanie godziny i daty itp.

3 O terapii logopedycznej z wykorzystaniem zeszytu pamięci napisali Karen Maxim i Jane Bryan [2006], Natalia Gawron [2008], Aneta Domagała [2014]. 
W odziaływaniach terapeutycznych przestrzegano następujących zasad wspomagających proces komunikacyjny [Kindell, Griffiths, 2006; Gustaw, 2007]:

1) budowanie zwięzłych, konkretnych komunikatów,

2) stosowanie podpowiedzi w postaci zadawania pytań pomocniczych, nakierowywania na zapomniane słowo,

3) dostosowanie tempa pracy do możliwości i potrzeb pacjenta,

4) wspomaganie komunikacji gestykulacją i rysunkiem,

5) stosowanie wzmocnień typu „tak”, „świetnie”, „dobrze”,

6) podtrzymywanie tematu rozmowy,

7) podążanie za pacjentem przez aktywne słuchanie, okazywanie zrozumienia, podtrzymywanie dialogu.

\section{Podsumowanie}

Przedstawiona terapia logopedyczna to propozycja rehabilitacji wielospecjalistycznej - ukierunkowanej na stymulację językową, komunikacyjną i poznawczą. Chociaż zaburzenia mowy w otępieniu alzheimerowskim mają charakter nieodwracalny i progresywny (niepomyślne rokowania), w prezentowanym przypadku po 12 miesiącach terapii zaobserwowano u pacjenta pozytywne skutki oddziaływań terapeutycznych. Prowadzona terapia korzystnie wpłynęła na zachowanie, samopoczucie i samoocenę pacjenta. Chory aktywnie uczestniczył w organizowanych sesjach terapeutycznych (tj. bloku zajęć stymulujących, aktywizujących). Co więcej, niejednokrotnie był inicjatorem rozmów, wyznaczając tym samym kierunek dalszych działań terapeutycznych. Mimo nasilających się trudności językowych, w tym szczególnie deficytów leksykalnych, pacjent był zmotywowany do pokonywania własnych barier językowych. Świadomie starał się przełamywać doświadczane trudności komunikacyjne. Świadczy to zatem o pozytywnym wpływie terapii.

$\mathrm{Na}$ dalszym etapie terapii logopedycznej działania terapeuty powinny być kontynuacją wcześniejszych strategii postępowania. Ponadto należałoby również włączyć w proces terapeutyczny oddziaływania o charakterze terapii pośredniej, czyli ukierunkowanej na pacjenta, będącej elementem codziennej opieki nad chorym i wsparcia udzielanego mu przez osoby z najbliższego otoczenia [Domagała, 2015b].

\section{Literatura}

American Psychiatric Association, 1994, Diagnostic and statistical manual of mental disorders, wyd. 4, Washington.

Antczak-Kujawin Justyna, 2017, O metodach badań sprawności leksykalno-semantycznej w otępieniu - zperspektywy logopedy, „Exlibris Biblioteka Gerontologii Społecznej”, nr 2(14), s. 118-128. 
Barcikowska Maria, 2012, Choroba Alzheimera - rozpoznawanie, [w:] Diagnostyka i leczenie otępień. Rekomendacje zespołu ekspertów Polskiego Towarzystwa Alzheimerowskiego, Otwock: Medisfera, s. 58-81.

Barcikowska Maria, Bilikiewicz Adam, 2004, Choroba Alzheimera w teorii i praktyce klinicznej, Lublin: Wydawnictwo Czelej.

Domagała Aneta, 2007, Zachowania językowe w demencji. Struktura wypowiedzi w chorobie Alzheimera, Lublin: Wydawnictwo Uniwersytetu Marii Curie-Skłodowskiej.

Domagała Aneta, 2014, Memory-books w terapii logopedycznej osób z otępieniem, [w:] D. Baczała, J.J. Błeszyński (red.), Terapia logopedyczna, Toruń: Wydawnictwo Naukowe Uniwersytetu Mikołaja Kopernika, s. 269-285.

Domagała Aneta, 2015a, Narracja i jej zaburzenia w otępieniu alzheimerowskim, Lublin: Wydawnictwo Uniwersytetu Marii Curie-Skłodowskiej.

Domagała Aneta, 2015b, Standardy postępowania logopedycznego w przypadku otępienia alzheimerowskiego, [w:] S. Grabias, J. Panasiuk, T. Woźniak (red.), Logopedia. Standardy postępowania logopedycznego. Podręcznik akademicki, Lublin: Wydawnictwo Uniwersytetu Marii Curie-Skłodowskiej, s. 995-1021.

Gawron Natalia, 2008, Metody oddziaływań niefarmakologicznych ukierunkowanych na poprawe funkcjonowania poznawczego, stanu psychicznego i zapobiegających występowaniu zaburzeń zachowania u pacjentów z chorobą Alzheimera, [w:] E. Łojek, A. Bolewska (red.), Wybrane zagadnienia rehabilitacji neuropsychologicznej, Warszawa: Wydawnictwo Naukowe Scholar, s. $123-155$.

Goodglass Harold, Kaplan Edith, 1983, The assessment of aphasia and related disorders, 2nd ed., Philadelphia: Lea \& Febiger.

Gustaw Katarzyna, 2007, KONTAKT - czyli strategie komunikacji z pacjentem z choroba Alzheimera, Warszawa: Wydawnictwo Ludbeck, s. 22-43.

Jodzio Krzysztof, 2011, Diagnostyka neurologiczna w praktyce klinicznej, Warszawa: Wydawnictwo Difin.

Kindell Jackie, Griffiths Harold, 2006, Speech and language therapy intervention for people with Alzheimer's disease, [w:] K. Bryan, J. Maxim (eds.), Communication Disabilities in the Dementias, Chichester: Whurr Publishers, s. 201-237.

Klasyfikacja zaburzeń psychicznych i zaburzeń zachowania w ICD-10. Opisy kliniczne i wskazówki diagnostyczne, 2000, Kraków-Warszawa: Vesalius.

Maxim Jane, Bryan Karen, 2006, Language, communication and cognition in the dementias, [w:] K. Bryan, J. Maxim (eds.), Communication Disabilities in the Dementias, Chichester: Whurr Publishers, s. 73-124.

McKhann Guy, Knopman David, Chertkow Howard i wsp., 2011, The diagnosis of dementia due to Alzheimer's disease: recommendations from the National Institute on Aging-Alzheimer's Association workgroups on diagnostic guidelines for Alzheimer's disease, „Alzheimer's Dementia", no. 3, s. 263-269.

Olszewski Henryk, 2008, Otępienie czołowo-skroniowe. Ujęcie neuropsychologiczne, Kraków: Oficyna Wydawnicza „Impuls”.

Szczudlik Andrzej (red.), 2016, Sytuacja osób chorych na chorobę Alzheimera w Polsce. Raport RPO, wyd. II, Biuro Rzecznika Praw Obywatelskich, Warszawa.

Szczudlik Andrzej, Parnowski Tadeusz, 2012, Otępienie, diagnostyka i leczenie otępień, Otwock: Medisfera. 
Streszczenie

W artykule przedstawiono opis przypadku 85-letniego mężczyzny z otępieniem alzheimerowskim w fazie łagodnej. Omówiono wyniki diagnozy logopedycznej i wskazano metody postępowania diagnostycznego. Opisano charakter zaburzeń mowy w otępieniu alzheimerowskim, ze szczególnym uwzględnieniem objawów zaburzeń sprawności leksykalno-semantycznej oraz sprawności narracyjnej. Wskazano również główne cele i strategie terapeutyczne oraz metody terapii logopedycznej stosowane w przypadku badanego pacjenta. Przedstawiono propozycję terapii logopedycznej, obejmującą opis pierwszych dwunastu miesięcy terapii.

\section{Summary}

The article presents the case study of 85 -year-old man with the early stage Alzheimer's dementia. The results of speech therapy diagnosis including the methods of diagnostic procedure were discussed. The nature of speech disorders in Alzheimer's dementia with particular focus on the symptoms of lexical and semantic skills as well as narration skills were described. The main objectives and therapeutic strategies were also indicated as well as the methods of speech therapy applied in the case of tested patient. The proposition of speech therapy including the description of first 12 months of therapy were presented. 